\title{
LIGHT ! CAMERA！ EDUCATION: THE USE OF CINEMA TO ENHANCE EDUCATION AND LEARNING
}

Alice Manuela Martins Guimares*

\begin{abstract}
In our time film making is regarded as a powerful teaching tool. Jean Mitry and Alain Bergala, amongst other filmmakers and writers associated with cinema, advocate that filmmaking is not just an art or a way to express culture, but it's also a way of acquiring knowledge. Bearing these thoughts in mind, we intend in this paper, to point out how learning and education come together in Willy Russell's film, Educating Rita. This film is based on the social constructivist notion advocated by Piaget (1896-1980) and Vygotsky (1896-1934), in which the determining factors for cognitive development interact with the physical and social environment, with human symbolism and with social interactions. Educating Rita refers to the social, historical and cultural context of the United Kingdom during the70's, and conveys how the educational process turns out to be a social practice. In this film the student is given a primary role, namely he is responsible for his own learning and proves he can find ways to achieve his goals and being responsible for the consequences of his choices, in a process of experiencing, reflecting and transforming himself through and educational experience he undergoes in adult. In addition to the importance of social context in education, the film focuses on the affective and educational issues and calls up a reflection on the affective dimension during the teaching-learning process.
\end{abstract}

Keywords: Cinema; Media; Learning and Education.

Today we live an unprecedented audio visual culture, where images exert the role of mediator between subject and culture. Most of young people form their intelligibility of the world from images. Actually nowadays, children and adolescents deal much easier with imagery language than with writing. Thus in the current context of technological innovations produced by the revolution of computerization and the spread of audiovisual media, digital and electronic teaching materials have gained new dimensions in its form, in its content and in its use. In this regard, Mitry stated (2000) " $t$ is our belief that cinema is not just an art, a culture, but a means to knowledge, i.e., not just a technique for disseminating facts but one capable of opening thought onto new horizons."

The inclusion of media instruments in different levels of education during the second half of the 20th century, was a necessary measure and tailored to students' cultural characteristics of modern society where the global communicative phenomenon took a huge social, cultural and educational relevance. In this context, cinema becomes a powerful teaching tool since it is a form of narrative that brings together a visual and auditory language whose connection provides a simultaneous dialogic and polyphonic 
language. The spectator gets vocal inflections, facial expressions and sounds which contribute to enhance the narration of the story. The film provides us living details of settings and locations that we may never have experienced before and it shows us all this in few minutes. Therefore the use of cinema as a vehicle and tool for teaching and learning promotes the approach of cultural, historical, political and literary aspects, providing its integral vision as an educational media. Any film portrays the thought and the human creation of a specific social model and of a specific historical moment, therefore it educates who assists, giving rise to a reflection and a subjective impression on the world.

Several filmmakers and writers associated with film research have developed opinions about cinema advocating that filmmaking is not just an art or a way to express culture, but it's also a way of acquiring knowledge. In this context, they defend the insertion of cinematic art in the school space as a pedagogical practice. Among these stands Alain Bergala who defines cinema as creation of knowledge and not just as pure consumption oriented to a bare entertainment. One of his the main contributions in his work ,The hypothesis - cinema (2006), is the idea that this art is an encounter with alterity. Another great supporter of a partnership between pedagogy and cinema is Henry A. Giroux. According to Giroux, the popular movies are nothing but a "form of public pedagogy - a visual technology that works as a powerful teaching machine" (Giroux, 2002:6). He also stated that

(...) it is a view that seems particularly out of date, if not irrelevant, given the important role that popular culture, including film, now plays pedagogically and politically in shaping the identities, values and broader social practices that characterize an increasingly postmodern culture in which the electronic media and visual forms constitute the most powerful educational tools of the new millennium (p. 6).

For Giroux, the film exerts an important influence on the public's imagination, since it produces ideologies and shapes individual and national identities. Giroux, in its combination of narratives, metaphors and images from popular culture, focus on the use of movies, supporting their arguments in the use of film as "pedagogical text."

The Italian researcher Pier Cesare Rivoltella, also adds that, once the cinema sets itself up as crossing of several socio-cultural practices, it becomes an "agent of socialization" that allows several and different meetings, such as: people with people into the cinema room; people with themselves; persons with the narratives of the movies; people with cultures within the various movie depictions; persons with multiple imaginaries, etc. (Rivoltella, 2008: 75). This "socialization agent" includes grown up population, in the context of lifelong learning.

Jean Mitry corroborates that "cinema is not just an art, a culture, but a means 106

Epiphany: Journal of Transdisciplinary Studies, Vol. 7. No. 2, (2014) (C Faculty of Arts and Social Sciences 
to acquire knowledge, i.e., it is not just a technique for the dissemination of facts, but a technique able to broaden the thinking towards new horizons." It is precisely through this technique of expanding knowledge and broadening our critical thinking that we can inscribe Willy Russell's film Educating Rita.

In 1980, the play of the same name, originally written to be represented in the theatre, had won the Laurence Olivier Award for the best comedy. Three years after the debut in 1983, the text of Russell would be adapted for cinema. Willy Russell, author of the screenplay, highlights the importance of the social context in education, conveying the social constructivist perspective of learning as advocated by Piaget (1896-1980) and Vygotsky (1896-1934).

This theoretical current emphasizes that the development of human intelligence is determined by mutual actions between the individual and the environment. It also suggests that the student is part of a social group and must have initiative to question, to discover and to understand the world from the interactions with the other elements of the historical context he belongs to. The main goal of a teacher is to encourage social interaction, stimulating the exchange of information in the pursuit of a collective and shared knowledge construction.

In the socio-constructivist perspective, the individual responds to external stimuli acting on them to build and organize his own knowledge. The student builds his knowledge, acting, running, building it from his social environment and from his relationship with the teacher(s). In such a relationship (between student/teacher) both of them are able to learn. It is this socio-constructivist approach that pervades Rita's learning and evolution in Russell's film Educating Rita. In this film, Rita, the main character, builds her knowledge as an adult student. Here the focus is given to the student who is responsible for her own learning and is able to find the paths to realize her potential, becoming responsible for the consequences of her choices, in a process of experiencing, reflecting and transforming herself. The film celebrates the potential freedom of education, as a force that allows people to open the doors of reality and of the vitality, of the working class to rise socially. At the same time, as does the main character, it is as a vehicle to discover herself, evolve intellectually and learn to make her own decisions.

Michael Caine starred as Frank, the tutor of Rita. Julie Walters starred as Rita (or Susan, her real name) and she is a restless student, hairdresser by profession, a married woman with no children, whose dreams were to break free from her social environment, become educated in order to find herself in life and have the freedom to make her own choices. Rita also dreamed of becoming a refined person.

For this purpose, she renounced to her origins and adopted a different name (Rita

Epiphany: Journal of Transdisciplinary Studies, Vol. 7. No. 2, (2014) (C) Faculty of Arts and Social Sciences 
in honor to Rita Mae Brown). This change, displays the enormous admiration that Rita had for the author of the book she was reading at the moment. Rita Mae Brown, the famous American writer, was a feminist activist, a great and a tireless fighter for the civil rights, who took part of the movement against the Vietnam War during the 1960s. The choice of this name shows Rita's dream of becoming an educated woman traveling the same path as the writer.

In its multi-faceted features Educating Rita addresses the difficult social issues of traditional beliefs about gender, class system and education. In this context, it reflects some of the epistemological issues of education, such as: who is the real agent in the educational process; the student's autonomy; the relationship between student and teacher; the reproduction of social practices and the voices of the participants involved in the learning process. Another relevant issue is the importance of critical thinking and of selfrespect as gateways to self-esteem and social acceptance.

Although Educating Rita is a fiction, it no longer provides us an authentic illustration of the English society of the 1970s. Nevertheless, the film has a gorgeous delicacy, dealing with the physical and spiritual desolation of Dr. Frank Bryant, the College Professor and with the vividness and intellectual curiosity of his student who made him rise out of a deeply decay and face the change as well.

The plot revolves around the relationship developed between Rita and Frank, the middle-aged college professor, during the school term, at the Open University. The action took place at Liverpool where Rita, dissatisfied with her working routine and social life, enrolled in the course of English Literature, searching for her inner growth. In this process, teacher and student developed an immediate understanding and the difference between their different worlds stimulated interest and mutual curiosity. Frank was a selfdestructive teacher, a person who seemed to be unable to maintain relationships and whose frustrations in life were shown through his profound drunkenness and incapacity to write the poetry he would like to produce.

Nevertheless he was an experienced teacher, smart and so unconventional that Rita immediately found out a similarity with her irrepressible desire to study. Thus she didn't hesitate when, at the beginning of the film Frank suggested her to get another tutor. In fact, initially, the teacher did not accept to be her tutor, but soon he would become rendered to her insistence, determination, purity and sincerity.

These features were something that Frank wasn't being able to find anymore, even in his personal and professional life. Everything about Rita was genuine, beginning with her pronunciation that informed her social origin, her typical accent from Liverpool, the use of slang in her speech, her personal outpourings, her dreams, the naive way of writing and telling what she was thinking about, etc. 
Her only trick was the nickname she used but that she explained naively. Susan, as it was her real Christian name, intended to become a counterpart of Rita Mae Brown. Suddenly the school started and sometimes Frank proved to be a much better teacher than he had ever thought. Rita's unassuming enthusiasm and honesty impressed him, making him (re-) examine his attitudes and positions in life. This enthusiasm of Rita would revitalize his numbed passion for teaching. On the other hand, the lessons with Frank opened Rita a new horizon, and she gradually acquired more self-esteem and selfconfidence.

Socially, Rita represents the lower class - the mass - which culture influences society's operations. As a working-class woman, she was socially and sexually confined. Social origins limited her choice to work, as well as all the other things in life - friends, relationships, romance, language, etc. In addition, her biological gender subdued her to her husband's domination, whose social backgrounds required him a masculinity that resulted in occasional domestic violence.

Actually the first time her husband (Denny) was presented on screen, he was demolishing the house while Rita was trying to write an essay, unsuccessfully. These details can suggest his husband's objection to study as well as a somehow sexist domination that was prone to physical violence. This violence was confirmed when he burned Rita's book. Nevertheless, Rita refused to accept these limitations imposed by birth and education. She rebelled against the conventionality of her class and broke up with it. Instead of having babies and settling down, as the traditionalist behavior of her class required, she decided to get an education so that she could have the opportunity to discover herself, to grow inward, to "sing a better song" as she put it in the film.

So, she learnt to dress up and talk with the accurate pronunciation and proper language, she gave up using slang, she learnt not to speak everything she thought but to think before to speak. This was something that reminds us Eliza Doolittle, the main character of George Bernard Shaw's Pygmalion. Rita realized that certain members of society had to "act", to be in tune with their lifestyles. We realize Rita's transformation when she felt the need to dress up to go to Frank's house at his invitation, and felt absolutely intimidated when she looked inside and listened to educated people talking in the lobby. She told Frank that she hadn't been brave enough to come in because she wouldn't know what to speak. However, Frank just answered her: "Nobody asked you to play a role! I only wished to have you there, just the way you are."

In which concerns socio cultural contrast, the film confronts: on the one hand, the pleasures of Frank and his friends Brian, his girlfriend Julia, and Trish, Rita's roommate as representatives of literature. Their academic formalities mask their social pretensions. On the other hand, Rita's natural liveliness dominates the representation of lower social 
class. We need to point out her joy, enthusiasm and determination as opposed to the academic class that seduced Rita so much. Frank's contempt for the academic world is displayed through the bottles of whisky hidden behind the endless rows of literary books in his office - a place that scared Rita on her first visit.

To highlight these social contrasts, Russell uses both the Liverpool accent, used by Rita and her husband and the accent of London, used by Frank and his friends. Once Rita comes from the working class she uses heavy accent and colloquial speech continuously. In this film, Willy Russell explicitly wants to criticize the social representation that makes each individual, an actor on the stage of life. Here, people learn how to behave according to their social class, they also learn what to wear and what to buy (Rita: dresses, Frank: books) Everything seems to be written into the script of their social lives as if every individual had pre-written functions, dialogues, costumes and actions that are expected to be followed to keep on this performance until a possible resolution may be reached.

Rita and Frank descriptions are convincingly realistic and are portrayed subtly in such an idiosyncratic way. Russell emphasizes their psychological depth, imbuing them with peculiar features which are neither transparent nor predictable. The two characters remained complex and multifaceted along the plot. Rita is impetuous but very sensitive. Frank is tired of teaching and is cynical but sometimes is sincere and sentimental. He is disillusioned with his job because he sees students as mere apprentices of all what had already been proven, not possessing an original thought. He's also an alcoholic who, among other factors, causes problems in his relationship with Julia, the woman with whom he lived with and in his professional life as well.

Rita belongs to the working class and feels ashamed of her roots. In her own words, "the only way to improve her home is through bombing." She had to go through an arduous process of education, to achieve her goal, which was to be able to display the intelligent discourse of scholars and the culture and elegance of the upper classes. All she wanted was to escape the life of her trivial family, neighbors and colleagues. Once her husband disapproved her decision to acquire other options in life radically, he burned Rita's books when he discovered that she was taking contraceptives. Rita's determination in pursuing her studies would cost her marriage because Denny decided to leave her.

As Rita became more and more educated she also increased her confidence and Frank, ironically, felt increasingly insecure. When she acquired "other teachers", for example, her summer school tutors or Trish, her roommate, Frank felt shaken because Rita's devotion was divided by other educators. He then found out escape in the usual bottles of whiskey and one day, after a discussion with his colleagues in University, he decided to go away to Australia. Rita was improving academically; however, she would naturally lose her naturalness and spontaneity. 
She learnt and adopted the necessary things that allowed her to "talk about things that really matter" - things than a cynic, even if a realistic one as Frank, would disdain. Frank witnessed Rita's transformation with a sad repudiation. In the process of educating herself, she lost the exclusivity that Frank more admired - her genuineness. And, at the end, when Frank asked her to go to Australia with him, suggesting a fresh start for both, she was evasive about starting a new life with him. Now she is polite so, as she put it, she had already the ability to choose and decide: "I might go to France. I might go to my mother's. I might even have a baby. I dunno. I'll make a decision, I'll chose. I dunno"(Russell, 1998:72-73) Throughout her learning process as an adult, Rita received guidance on literary theories and conventional critical thinking. She learnt to question and address literature objectively and critically. The ability to discuss and to argue gives her a broader view about her options in life and provides her what she had set out seeking - life choices.

This film explores much more than the simple matter of education. Relations between student-teacher and the common sharing of experiences and learning, which are assumptions from the socio-constructivist approach of education, are some of the matters the film informs. In fact, we realized the way Rita and Frank could influence each other. The relationship between Rita and Frank calls up towards, not only the mutual friendship, but also towards the mutual intellectual support. Frank learns much about Rita, as she learns from him.

While Rita gains self-confidence, through the awareness that her options are no longer limited, Frank gets his self-esteem back through the respect that Rita had for him. The teacher finally learnt to respect and to believe in himself. Furthermore, he learnt to respect his students when he realized that each ability to learn is unlimited, and that not all students were so terrible as he had thought. To sum up, Educating Rita explores the multiple issues relating to choices, relationships, social classes and education.

The main character of the film is an excellent example of a working-class citizen of the 70s society in the United Kingdom, living in a city with a huge level of unemployment and trying to make her choices in life through education. Rita figured out that only education would help her to raise socially and to have a better quality of life. She then tried to meet herself through Education. In the multitude of possible discussions due to the richness of Russell's screenplay, this essay has chosen to explore the idea of liberal education designed by divergent views and the way in which this type of education can fulfill dreams and ensure changes in people's lives. In addition, it focuses on the relationships of affectivity and complementarily between student and teacher which foster the evolution of each person and raise change. Maybe the specific topic of change is the one that most calls together both the student's character within the plot, as the viewer, inside the cinema. In general the film Educating Rita, stresses the importance of critical 
thinking and self-respect as gateways to self-esteem and social acceptance. The film displays how the way educational process turns out to be a social practice and how cinema and education can come together in the teaching process.

\section{References:}

Bergala, Alain. 2006. L'hypothèse - cinéma: petit traité de transmission du cinéma à l'école et ailleurs. [A hipótese-cinema: pequeno tratado de transmissão do cinema dentro e fora da escola. Tradução: Mónica Costa Netto, Silvía Pimenta, Rio de Janeiro: Booklink; CINEAD-LISE/FE/UFRJ, 2008].

Giroux, Henry, A. 2002. Breaking In to the Movies: Film and the Culture of Politics, Basil Blackwell Press, Oxford, UK.

Mitry, Jean. 2000. Semiotics and the Analysis of Film, The Athlon Press, UK.

Rivoltella, Píer Cesare. 2008. A Formação da Consciência Civil entre o "real" e o "virtual", in: Girardello, Gilka e Fantin, Mónica, Liga, roda, clica: Estudos em mídia, infância e cultura, Campinas, Papirus.

Russell, Willy. 1998. Educating Rita (film), Singapore: Longman Group Ltd. 